\title{
Spinal cord blood flow changes following systemic hypothermia and spinal cord compression injury: an experimental study in the rat using Laser-Doppler flowmetry
}

\author{
H Westergren*,1, M Farooque ${ }^{2}$, Y Olsson $^{2}$ and A Holtz ${ }^{1}$ \\ ${ }^{1}$ Unit of Neurosurgery, Department of Neuroscience, Uppsala University, Sweden; ${ }^{2}$ Laboratory of Neuropathology, \\ Department of Genetics and Pathology, Uppsala University, Sweden
}

\begin{abstract}
Study design: It is well known that changes of the body temperature as well as trauma influence the blood flow in the brain and spinal cord. However, there is still a lack of knowledge concerning the levels of blood flow changes, especially during hypothermia.

Objectives: This investigation was carried out to examine the effects of systemic hypothermia and trauma on spinal cord blood flow (SCBF).

Methods: Twenty-four rats were randomized either to thoracic laminectomy only (Th VII IX) or to $35 \mathrm{~g}$ spinal cord compression trauma. The animals were further randomized to either constant normothermia $\left(38^{\circ} \mathrm{C}\right)$ or to a systemic cooling procedure, ie reduction of the esophageal temperature from 38 to $30^{\circ} \mathrm{C}$. SCBF was recorded $5 \mathrm{~mm}$ caudal to the injury zone using Laser-Doppler flowmetry which allows a non-invasive continuous recording of local changes in the blood flow. The autoregulation ability was tested at the end of the experiments by inducing a $30-50 \mathrm{mmHg}$ blood-pressure fall, using blood-withdrawal from the carotid artery.

Results: The mean SCBF decreased $2.8 \%$ and $3.5 \%$ per centigrade reduction of esophageal temperature in the animals sustained to hypothermia with and without trauma, respectively. This could be compared to a decrease of $0.2 \% / \mathrm{min}$ when only trauma was applied. No significant differences were seen between the groups concerning auto regulatory ability.

Conclusions: Our results indicate that the core temperature has a high impact on the SCBF independent of previous trauma recorded by Laser-Doppler flowmetry. This influence exceeds the response mediated by moderate compression trauma alone.
\end{abstract}

Sponsorship: The study was supported by grants from the Laerdal foundation.

Spinal Cord (2001) 39, 74-84

Keywords: hypothermia; rat; spinal cord injury; blood-flow; Laser-Doppler

\section{Introduction}

Trauma to the brain and spinal cord causes primary damage to the nervous tissue followed by a cascade of events often referred to as secondary injury mechanisms. ${ }^{1,2}$ During the last decade, much effort has been made on the mapping and understanding of different aspects of these mechanisms, such as the role of excitotoxic factors, ${ }^{3}$ free radical formation, ${ }^{4}$ apoptosis of the glial cells and neurons, 5,6 and the effect of vascular changes. ${ }^{7,8}$ Even if much knowledge has been accumulated there is still a need to understand further these pathophysiological processes and to find alternative ways of affecting them. To that end we have started a series of investigations to map the role of systemic hypothermia following spinal cord trauma. ${ }^{9}$

*Correspondence: H Westergren, Department of Neurosurgery, University Hospital, S-751 85 Uppsala, Sweden
In the present study we have investigated, by LaserDoppler flowmetry, the influence of systemic hypothermia on post-traumatic spinal cord blood flow (SCBF), and the autoregulation ability following trauma.

The Laser-Doppler technique has been used for almost two decades in the assessment of microcirculatory changes of the brain and spinal cord. ${ }^{10,11}$ Several studies have been performed comparing the results of Laser-Doppler flowmetry to other means of recording microcirculation, such as the $\mathrm{H}_{2}$-clearance technique, ${ }^{12}$ and cranial window technique. ${ }^{14}$ In these comparisons simultaneous recordings have shown linear relationships between relative changes of the Laser-Doppler signal and the parameters of the other methods. The Laser-Doppler technique is easy to use, non-invasive and changes of the SCBF flow can be recorded on-line. The major disadvantages with the technique is that it does not allow recordings of 
absolute SCBF values, the knowledge of the tissue volume in which the blood flow is recorded is limited and the method is very sensitive to artifacts. ${ }^{10,11,15}$ The effect of spinal cord trauma on the SCBF has been extensively investigated. A vast majority of these studies confirm a post traumatic hypo-perfusion in the traumatized and adjacent segments of the spinal cord due to vascular damage, vasospasm and the formation of thromboses. ${ }^{7,16,17}$ Many of the SCBF studies following spinal cord trauma have been performed using invasive methods, giving 'snap-shots' of the SCBF with excellent anatomical resolution but only allowing one measurement per animal. ${ }^{18}$ The use of a non-invasive on-line technique could therefore be of great value in increasing the knowledge of SCBF changes during and following trauma, and in the evaluation of therapeutic measures in the acute stage.

The CNS blood flow is kept constant, under normal circumstances, as an effect of the interplay between the myogenic and metabolic autoregulation. ${ }^{19,20}$ In the normal rat spinal cord the myogenic autoregulation provides a constant SCBF between MABP 45 to $165 \mathrm{mmHg} .{ }^{20}$ However, following spinal cord trauma, disturbances of the myogenic ${ }^{21}$ and metabolic autoregulation occur. $^{22}$ During normothermia, areas of both post-traumatic hyper- and hypoperfusion will arise as a result of altered arteriolar diameters and impaired $\mathrm{CO}_{2}$ reactivity.

Systemic hypothermia induces an immediate decrease in cerebral metabolism ${ }^{23-26}$ as well as cerebral blood flow. ${ }^{27}$ However, knowledge of SCBF and hypothermia is very sparse to date. Sakamoto and Monafo report an increase in SCBF following systemic hypothermia ${ }^{28}$ while local cooling, on the other hand, seems to decrease the SCBF. ${ }^{29,30}$

This study was set up to evaluate the effects of systemic hypothermia following spinal cord compression trauma. We have investigated the effects of systemic hypothermia on the post-traumatic SCBF and the autoregulatory ability of the spinal cord, as measured by Laser-Doppler technique for continuous recording of blood flow changes.

\section{Materials and methods}

\section{Animal preparation}

Twenty-four male Sprague-Dawley rats with a body weight of $350-420 \mathrm{~g}$ were used. Food and water were provided ad libitum and the animals were kept at a controlled temperature of $20^{\circ} \mathrm{C}$ and exposed to alternate light and dark periods of $12 \mathrm{~h}$. The study was approved by the Uppsala Ethical Committee for Animal Research. The animals were anesthetized by a subcutaneous (sc) bolus injection of Hypnorm ${ }^{\mathbb{R}} /$ Dormicum $^{\mathbb{R}}\left(1\right.$ part Hypnorm $^{\circledR}+1$ part Dormicum $^{\mathbb{B}}+2$ parts distilled water: $1.5-2.0 \mathrm{ml} / \mathrm{kg}$ ). Additional small doses were administered $\mathrm{sc}$ at regular intervals throughout the experiment. A catheter (PE 50) was inserted into the tail artery for blood sampling and blood pressure recording. Another catheter (PE 60) was inserted in the right carotid artery for rapid blood evacuation. After tracheotomy the animals were connected to a small-animal respirator (Harvard type), and the blood gases were adjusted to $\mathrm{PCO}_{2} 4.5-$ $5.5 \mathrm{kPa}$ and $\mathrm{PO}_{2} 9-19 \mathrm{kPa}$.

A laminectomy of the Th VII-IX vertebrae was performed after which the animals were placed in a stereotaxic frame resting on a heating plate, leaving the head and neck unheated (Figure 1). A single intramuscular dose of $1.0 \mathrm{mg}$ Pavulon ${ }^{\circledR}$ (Pancuronium bromide) was administered prior to the LaserDoppler recording, in order to avoid movements.

\section{Body temperature management}

The temperature in the laboratory was set to $20^{\circ} \mathrm{C}$. The animals' core temperatures were obtained in the esophagus close to the heart. This location has been demonstrated to give temperature recordings that correlate to the temperature in the epidural space. ${ }^{9}$ An electronic thermometer (Thermalert, TH-5, Physitemps Instruments Inc., New Jersey, USA) was used together with a thermocouple (IT-18). In the normothermic procedure the animals' esophageal temperature was maintained at around $38^{\circ} \mathrm{C}$ using the heating plate (Figure 1). The cooling from 38 to $30^{\circ} \mathrm{C}$, ie the criteria for the hypothermic groups, was achieved by wetting the animals with a $20 \%$ ethanol solution and turning off the heating plate. This body temperature reduction is attained after about $30 \mathrm{~min} .{ }^{9}$

\section{Trauma and Laser-Doppler probe application}

The compression trauma to the spinal cord was induced by means of a specially designed device. ${ }^{17} \mathrm{~A}$ $35 \mathrm{~g}$ weight placed on a curved rectangular plate $(2.2 \times 5 \mathrm{~mm})$ was applied on the intact dura for $5 \mathrm{~min}$ (Figure 1). The compression was located in the cranial part of the laminectomy (Th VII-VIII), which corresponds to Th VIII-IX segments of the spinal cord. From previous studies this compression has been shown to cause hematomas and necrotic changes in the compressed area as well as SCBF changes in the compressed area and peri-injury zones. ${ }^{17}$

The Laser-Doppler probe was then applied in the most caudal part of the laminectomy. The wound was sutured carefully, enclosing the forceps, and leaving a small gap for the Laser-Doppler probe. This gap was covered with a compress to avoid influence from the light in the room. The combination of the animal and probe fixation in the specially designed framework and the addition of muscular relaxants made it possible to avoid any movements of the probe.

\section{Blood-flow recordings}

The blood-flow changes were recorded using LaserDoppler technique. ${ }^{10}$ Pf2b Helium-Neon Laser-Doppler equipment (Perimed AB, Järfälla, Sweden) with a 
wave length of $632.8 \mathrm{~nm}$ was used, together with a specially designed probe (Pf 315-145) with fiber separation $0.5 \mathrm{~mm}$. The outer probe tip diameter was $1.6 \mathrm{~mm}$, which corresponds to the maximum diameter allowing free adjustment space for the probe within the laminectomy. The Laser-Doppler device was calibrated using a latex solution in accordance with the instructions from the manufacturer. The probe was attached to a micro manipulator and the tip applied in the most caudal part of the laminectomy (Figure 1). This position corresponds to the vertebra Th IX, ie the Th X segment of the spinal cord. In the trauma groups the caudal end of the compression plate was sited approximately five $\mathrm{mm}$ from the Laser-Doppler probe during the compression trauma. This is the shortest distance that allows continuous contact between the dura and the Laser-Doppler probe during the spinal cord compression.

The experiment was continued when a stable signal of at least $40 \mathrm{mV}$ (perfusion units) amplitude was obtained for $5 \mathrm{~min}$. The sampling time was adjusted to $3 \mathrm{~s}$. The mean amplitude of this first 5 min LaserDoppler recording was defined as the base-line from which the blood-flow changes were calculated.

\section{Experimental groups}

The animals were randomized to either laminectomy only or to a $35 \mathrm{~g}$ spinal cord compression trauma (Table 1). They were further randomized to either

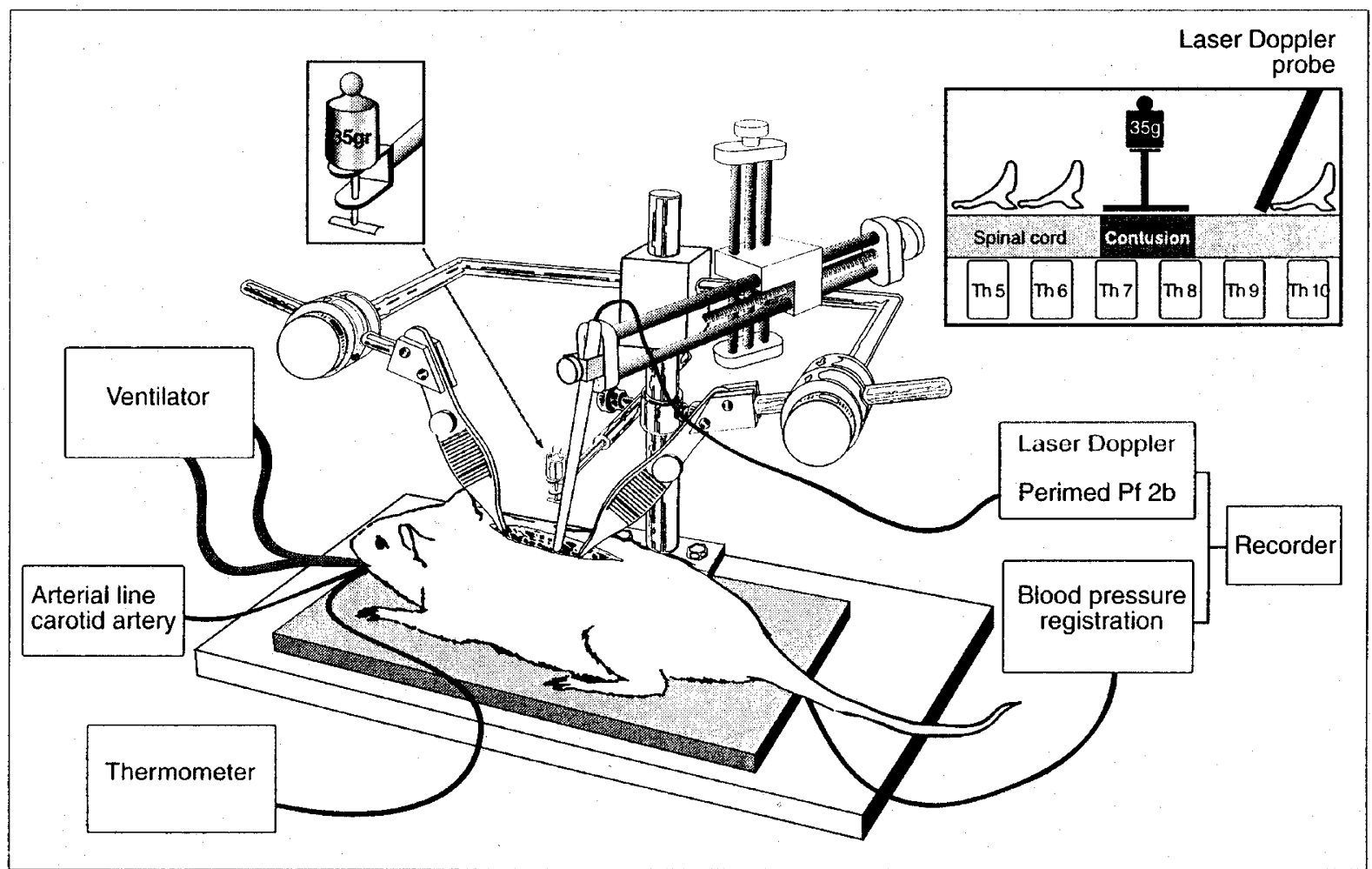

Figure 1 Artist's view of the experimental set-up

Table 1 The experimental groups

\begin{tabular}{|c|c|c|c|c|c|}
\hline $\begin{array}{l}\text { Group } \\
\text { no. }\end{array}$ & Name in text & Surgical procedure & $\begin{array}{l}\text { Normothermic } \\
\text { steady-state period }\end{array}$ & $\begin{array}{l}\text { Temperature } \\
\text { management }\end{array}$ & $\begin{array}{c}\text { Auto-regulation } \\
\text { test }\end{array}$ \\
\hline 1 & $\begin{array}{l}\text { Normothermic non- } \\
\text { trauma group }\end{array}$ & Laminectomy & 45 min after preparation & $\begin{array}{c}\text { Constant normothermia } \\
\left(38^{\circ} \mathrm{C}\right)\end{array}$ & + \\
\hline 2 & $\begin{array}{c}\text { Hypothermic } \\
\text { non-trauma group }\end{array}$ & Laminectomy & 15 min after preparation & $\begin{array}{l}\text { Systemic cooling } \\
\left(38 \rightarrow 30^{\circ} \mathrm{C}\right)\end{array}$ & + \\
\hline 3 & $\begin{array}{l}\text { Normothermic } \\
\text { trauma group }\end{array}$ & $\begin{array}{l}35 \mathrm{~g} \text { compression } \\
\text { trauma }\end{array}$ & 45 min after trauma & $\begin{array}{c}\text { Constant normothermia } \\
\left(38^{\circ} \mathrm{C}\right)\end{array}$ & + \\
\hline 4 & $\begin{array}{l}\text { Hypothermic } \\
\text { trauma group }\end{array}$ & $\begin{array}{l}35 \text { g compression } \\
\text { trauma }\end{array}$ & 15 min after trauma & $\begin{array}{l}\text { Systemic cooling } \\
\quad\left(38 \rightarrow 30^{\circ} \mathrm{C}\right)\end{array}$ & + \\
\hline
\end{tabular}


constant normothermia or to the systemic cooling procedure. These two randomizations resulted in four groups with six animals in each group.

Group 1 Normothermic non-trauma group. The animals underwent laminectomy only, and the body temperature was kept close to $38^{\circ} \mathrm{C}$ during the experiment. The Laser-Doppler recording was performed during $45 \mathrm{~min}$ of normothermic steady-state $\left(38^{\circ} \mathrm{C}\right)$.

Group 2 Hypothermic non-trauma group. The same surgical procedure was performed as in group 1. In addition, after a period of $15 \mathrm{~min}$ normothermic steady-state, the systemic cooling procedure was carried out, reducing the core temperature from 38 to $30^{\circ} \mathrm{C}$. The Laser-Doppler recording was continued until the core temperature reached $30^{\circ} \mathrm{C}$.

Group 3 Normothermic trauma group. The LaserDoppler recording was performed before and during the $5 \mathrm{~min}$ compression trauma and during the following $45 \mathrm{~min}$ of normothermic steady-state $\left(38^{\circ} \mathrm{C}\right)$.

Group 4 Hypothermic trauma group. The LaserDoppler recording was performed during the trauma, as in group 3 , and was continued during the cooling procedure from 38 to $30^{\circ} \mathrm{C}$, which was induced $15 \mathrm{~min}$ after the trauma.

\section{Autoregulation test}

The autoregulation, ie the ability of maintaining constant blood flow despite alterations in blood pressure, was tested at the end of the experiments. The animals were sacrificed directly afterwards. In the normothermic non-trauma group the tests were performed after the $45 \mathrm{~min}$ steady-state period; in the normothermic trauma group, $45 \mathrm{~min}$ after the trauma; and in the hypothermic group, when the core temperature had reached $30^{\circ} \mathrm{C}$. At the starting point the MABP and the SCBF were recorded simultaneously. A blood-pressure fall was induced by extracting blood from the catheter in the right carotid artery, in order to achieve a MABP of 60$70 \mathrm{mmHg}$. The MABP and SCBF were recorded as follows: (0) at the lowest point of MABP; (3) 3 and (6) 6 min later.

\section{Physiological parameters}

Physiological parameters such as blood gases and blood (B) glucose, sodium, potassium and calcium were recorded directly after preparation and after the autoregulation test using the extracted blood. The hematocrit (EVF) could only be recorded in the last blood sample since $0.5 \mathrm{ml}$ of blood was required for that analysis. The blood samples were analyzed in a blood gas/electrolyte analyzer (IL 1640; ILS Labora- tories, Scandinavia $\mathrm{AB}$ ). The temperature calibration was maintained at $37^{\circ} \mathrm{C}$.

\section{Data evaluation}

The SCBF values are referred to as percentage of the mean value of the amplitude during the base-line recording. The MABP is referred to in actual values.

The SCBF and MABP were recorded every $5 \mathrm{~min}$ during the normothermic steady states and at every $1^{\circ} \mathrm{C}$ change in core temperature during the hypothermic procedures.

The mean SCBF values were compared at three equivalent points (Figure $2 \mathrm{a}-\mathrm{d}$ ): in the normothermic non-trauma group, after $15 \mathrm{~min}$ (a), $30 \mathrm{~min}$ (b) and $45 \mathrm{~min}$ (c) of $\mathrm{SCBF}$ recording (Figure 2a); in the normothermic trauma group, $15 \mathrm{~min}$ (a), $30 \mathrm{~min}$ (b) and $45 \mathrm{~min}$ (c) after the compression trauma (Figure 2c); in the hypothermic groups, before the cooling procedure (a), at $34^{\circ} \mathrm{C}$ (b) and $30^{\circ} \mathrm{C}$ (c; Figure 2b,d).

The mean values for the groups are given \pm SD. Simple linear regression analysis was used in the evaluation of mean SCBF changes. Anova and Fisher's post hoc test (SuperAnova, Abacus Concepts, Inc. Berkeley, CA, USA) were used to evaluate mean SCBF differences between the groups. Differences with a $P$ value $<0.05$ were considered significant and are denoted with asterisks in figures and tables.

\section{Results}

Five animals that passed the preparation procedure were excluded. In three of the animals, stable LaserDoppler recordings could not be obtained. The other two animals were excluded because of unstable blood pressure.

\section{Physiological parameters}

No significant changes were seen in B-Glucose, BSodium, B-Calcium or $\mathrm{pH}$ in any group between the two recordings (Tables 2 and 3 ). The cooling procedure resulted in significant changes in BPotassium and $\mathrm{PO}_{2} . \mathrm{PCO}_{2}$ increased in all groups, and altered base excess and standard bicarbonate were seen in groups 1, 3 and 4 . No differences were observed in the animals' body weight or in the preparation time (data not presented).

\section{$M A B P$ and $S C B F$ changes}

Group 1 Normothermic non-trauma group: The recordings of MABP varied between $90-110 \mathrm{mmHg}$ resulting in mean values $98 \pm 6$ to $101 \pm 7 \mathrm{mmHg}$ during the $45 \mathrm{~min}$ observation period (Figure $2 \mathrm{a}$ ).

The variation of $\mathrm{SCBF}$ recordings was $88 \%$ to $120 \%$ of the base-line value. The mean value of all SCBF recordings in the group was $101 \pm 7 \%$. 
Regression analysis (SCBF vs time) showed a low correlation coefficient $\left(\mathrm{r}^{2}: 0.11\right)$.

Group 2 Hypothermic non-trauma group. The recordings of MABP varied between $90-105 \mathrm{mmHg}$ during the entire experiment (mean $92 \pm 7$ to $99 \pm 5 \mathrm{mmHg}$; Figure 2b).

The SCBF varied between 95 and $104 \%$ of the baseline recording during the first 15 min of normothermic steady-state. The mean value was $98 \pm 3 \%$ and did not
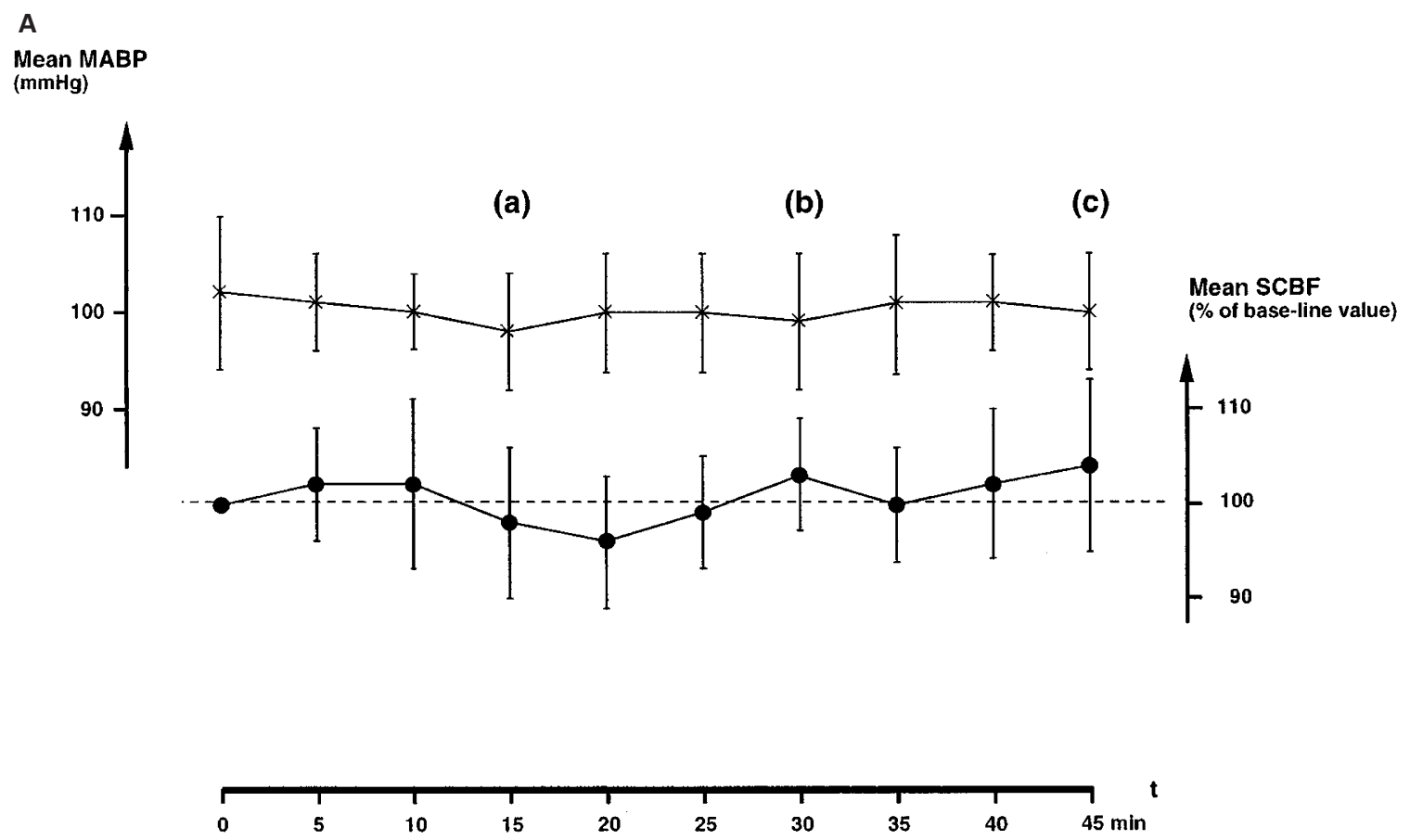

Group 1: Normothermia $\left(38^{\circ} \mathrm{C}\right)$ without trauma

B

Mean MABP $(\mathrm{mmHg})$
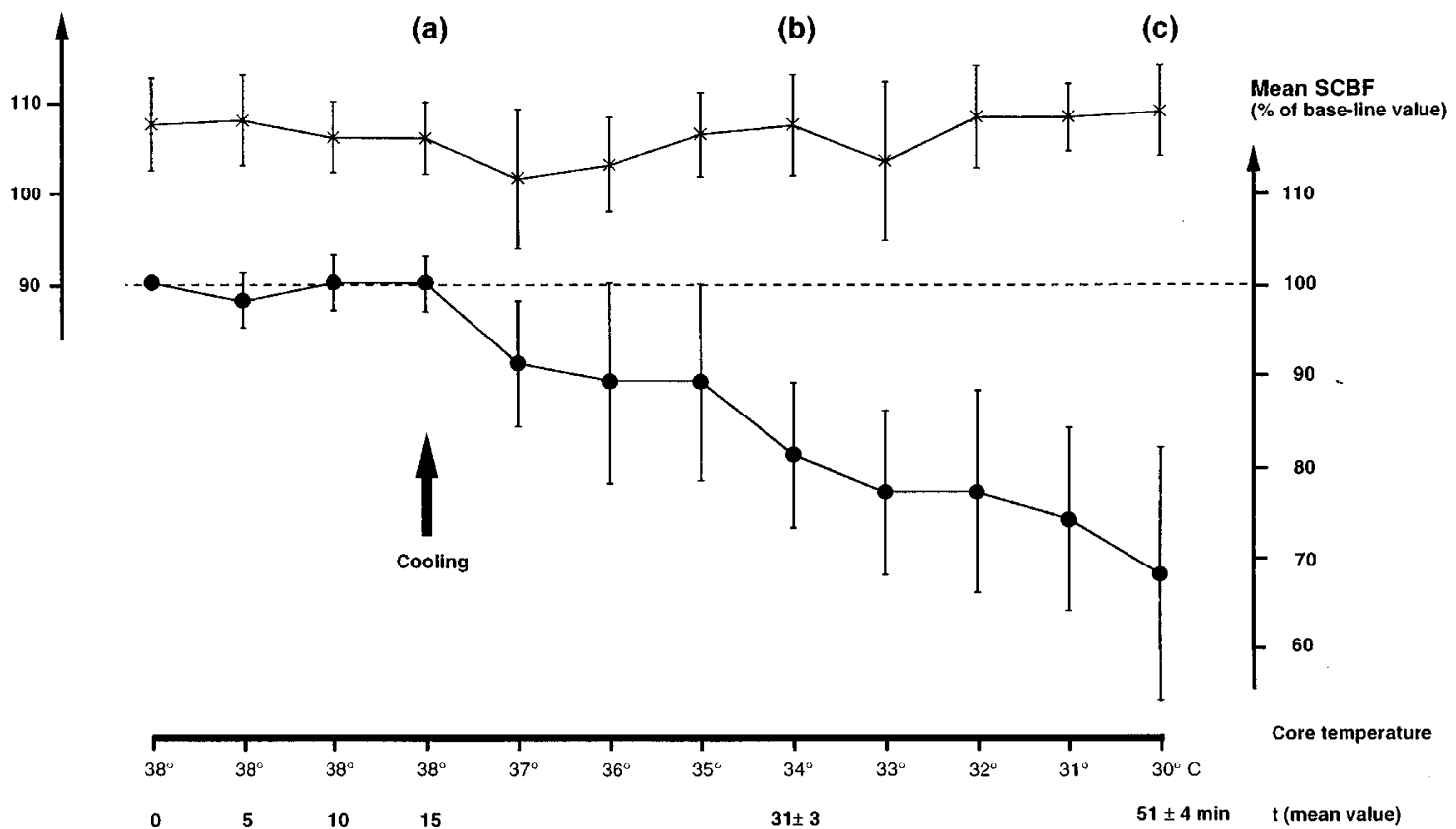

Group 2: Hypothermia without trauma 
C

Mean MABP

$(\mathrm{mmHg})$
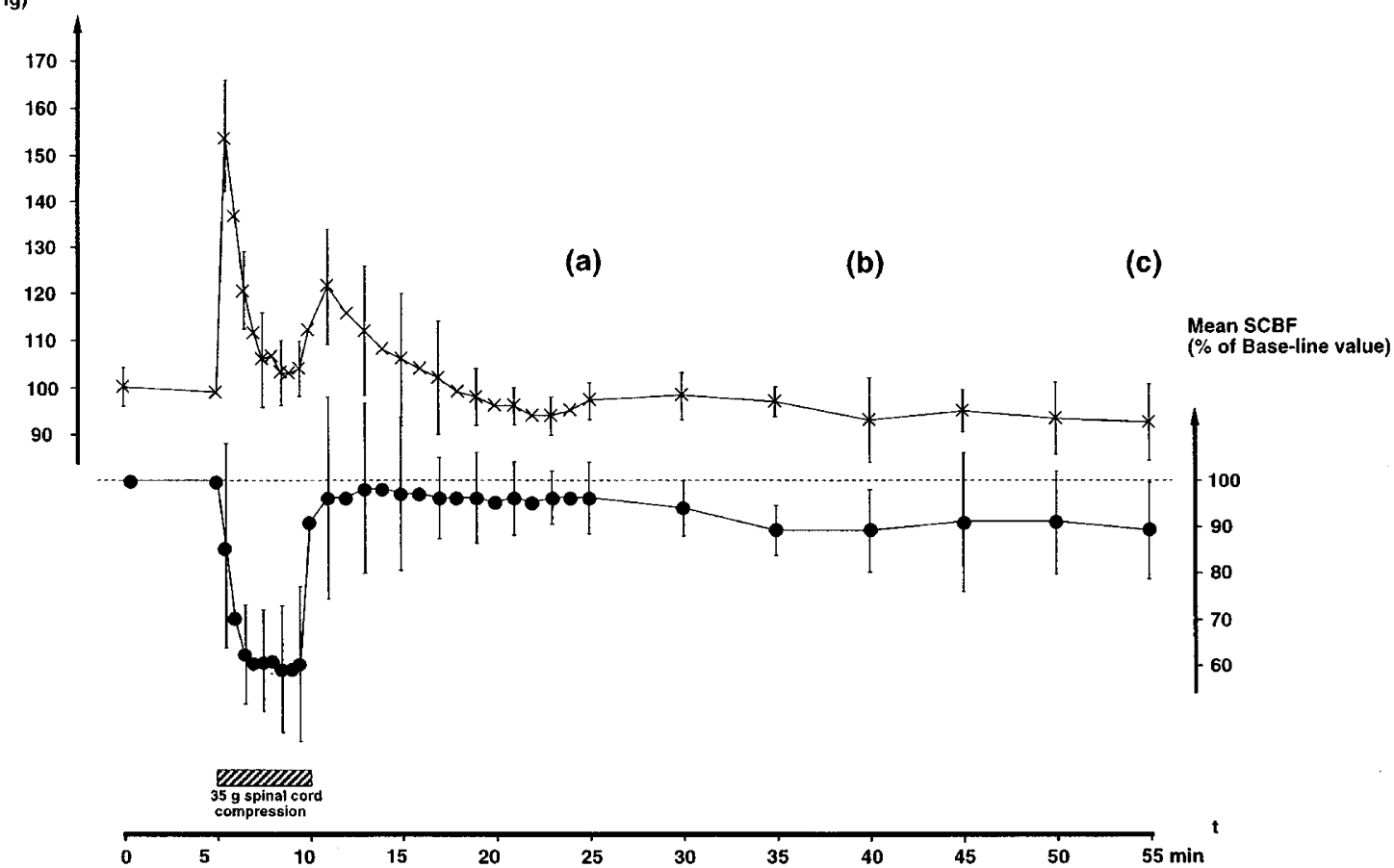

Group 3: Normothermia $\left(38^{\circ} \mathrm{C}\right)$ with $35 \mathrm{~g}$ compression trauma

D

Mean MABP $(\mathrm{mmHg})$

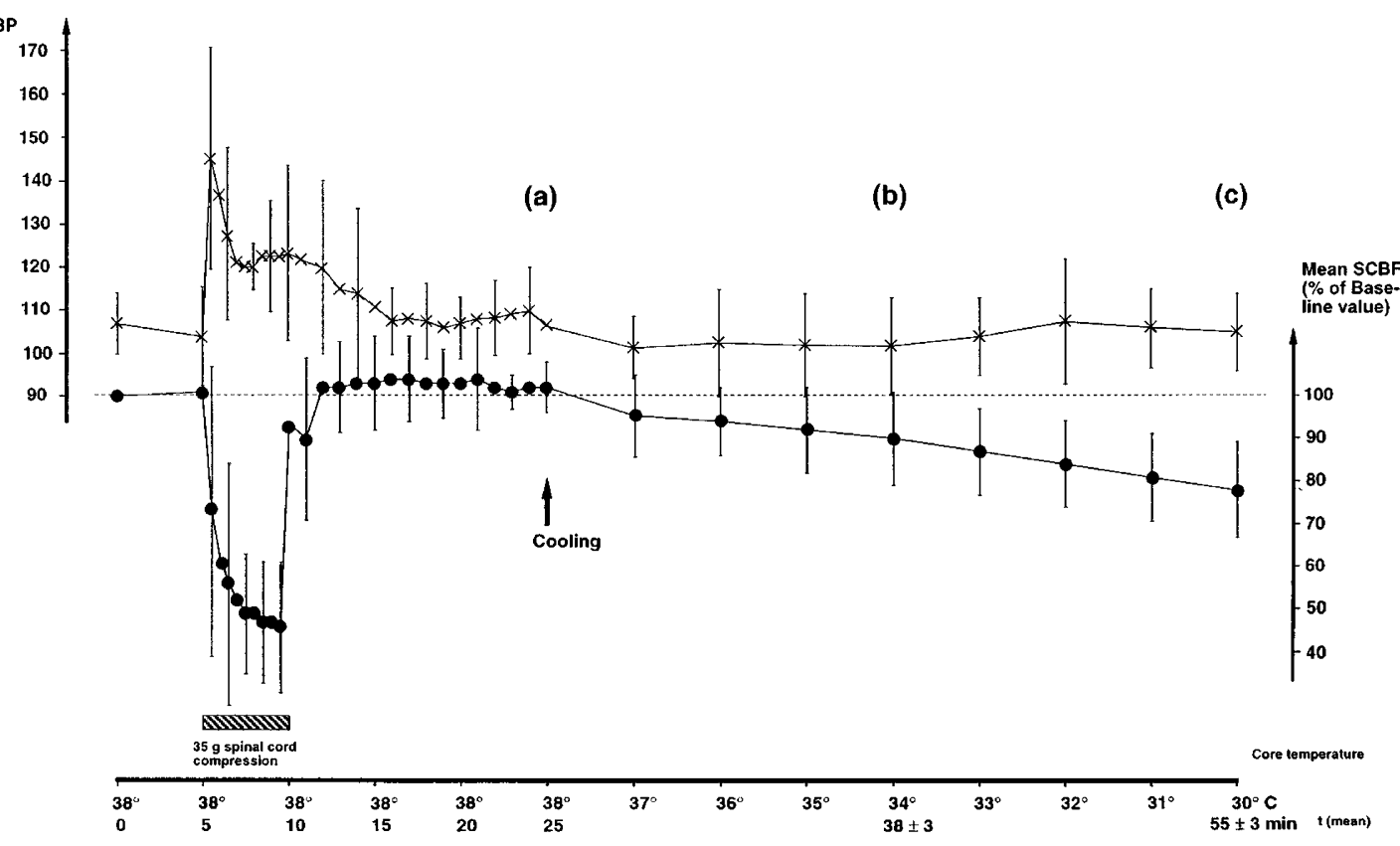

Group 4: Hypothermia with $35 \mathrm{~g}$ compression trauma

Figure 2 (a-d) Mean MABP in actual values \pm SD $(\times)$ and SCBF in per cent $(\%)$ of base-line recordings \pm SD $(0)$. The mean SCBF values were compared between the groups at three equivalent points (a), (b), and (c). For calculations see Table 4. (a) Normothermic non-trauma group. (b) Hypothermic non-trauma group. The arrow indicates the start of the cooling procedure. (c) Normothermic trauma group. (d) Hypothermic trauma group. The arrow indicates the start of the cooling procedure 
Table 2 Physiological parameters recorded after the preparation and after the autoregulation test in the end of the experiment

\begin{tabular}{|c|c|c|c|c|c|c|c|c|c|c|c|}
\hline & & $\begin{array}{r}\begin{array}{r}B-G l \\
(\mathrm{~mm}\end{array} \\
\text { After } \\
\text { preparation }\end{array}$ & $\begin{array}{l}\text { lcose } \\
\mathrm{ol} / 1) \\
\text { After auto- } \\
\text { regulation } \\
\quad \text { test }\end{array}$ & $\begin{array}{r}\begin{array}{r}B-S o \\
(\mathrm{~mm}\end{array} \\
\text { After } \\
\text { preparation }\end{array}$ & $\begin{array}{l}\text { dium } \\
\text { ol/1) } \\
\text { After auto- } \\
\text { regulation } \\
\quad \text { test }\end{array}$ & $\begin{array}{r}\text { B-Pot } \\
(\mathrm{mm}\end{array}$ & $\begin{array}{l}\text { assium } \\
\text { 1ol/1) } \\
\text { After auto- } \\
\text { regulation } \\
\quad \text { test }\end{array}$ & $\begin{array}{r}B-C a \\
(\mathrm{~mm}\end{array}$ & $\begin{array}{l}\text { cium } \\
\text { ol/l) } \\
\text { After auto- } \\
\text { regulation } \\
\quad \text { test }\end{array}$ & \begin{tabular}{r}
$E \mathrm{E}$ \\
$(\mathrm{o}$ \\
\multicolumn{2}{c}{ After } \\
preparation
\end{tabular} & $\begin{array}{l}F \\
\text { After auto- } \\
\text { regulation } \\
\text { test }\end{array}$ \\
\hline Group 1 & $\begin{array}{l}\text { Normothermia no } \\
\text { trauma }\end{array}$ & $6.4 \pm 1.2$ & $7.0 \pm 2.2$ & $135 \pm 4$ & $136 \pm 3$ & $4.7 \pm 0.5$ & $5.0 \pm 0.6$ & $1.4 \pm 0.0$ & $1.3 \pm 0.1$ & - & $35 \pm 5$ \\
\hline Group 2 & $\begin{array}{l}\text { Hypothermia no } \\
\text { trauma }\end{array}$ & $8.4 \pm 1.1$ & $9.1 \pm 1.2$ & $137 \pm 5$ & $138 \pm 1$ & $5.0 \pm 0.7$ & $3.4 \pm 0.3^{*}$ & $1.4 \pm 0.1$ & $1.4 \pm 0.0$ & - & $37 \pm 2$ \\
\hline Group 3 & $\begin{array}{l}\text { Normothermia } \\
\text { trauma }\end{array}$ & $8.6 \pm 0.7$ & $7.6 \pm 1.4$ & $138 \pm 3$ & $138 \pm 2$ & $4.7 \pm 0.4$ & $5.0 \pm 0.4$ & $1.4 \pm 0.1$ & $1.3 \pm 0.0$ & - & $36 \pm 3$ \\
\hline Group 4 & Hypothermia trauma & $9.2 \pm 1.1$ & $9.7 \pm 1.5$ & $136 \pm 2$ & $136 \pm 3$ & $4.6 \pm 0.6$ & $3.5 \pm 0.3 *$ & $1.4 \pm 0.1$ & $1.4 \pm 0.1$ & - & $37 \pm 4$ \\
\hline
\end{tabular}

*Indicates significant difference $v s$ the preparation value. $P<0.05$

Table 3 Physiological parameters recorded after the preparation and after the autoregulation test in the end of the experiment

\begin{tabular}{|c|c|c|c|c|c|c|c|c|c|c|c|}
\hline & & $\begin{array}{r}\qquad \\
\qquad \begin{array}{l}\text { After } \\
\text { preparation }\end{array}\end{array}$ & $\begin{array}{l}\text { pHfter auto- } \\
\text { regulation } \\
\text { test }\end{array}$ & 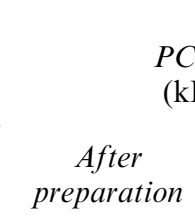 & $\begin{array}{l}\mathrm{CO}_{2} \\
\mathrm{~Pa}) \\
\text { After auto- } \\
\text { regulation } \\
\quad \text { test }\end{array}$ & \begin{tabular}{r}
$P$ \\
\\
\\
\multicolumn{2}{c}{ After } \\
preparation
\end{tabular} & $\begin{array}{l}\mathrm{O}_{2} \\
\mathrm{~Pa}) \\
\text { After auto- } \\
\text { regulation } \\
\text { test }\end{array}$ & $\begin{array}{r}\begin{array}{r}\text { Base } \\
(\mathrm{mm}\end{array} \\
\text { After } \\
\text { preparation }\end{array}$ & $\begin{array}{l}\text { excess } \\
\text { nol/l) } \\
\text { After auto- } \\
\text { regulation } \\
\quad \text { test }\end{array}$ & $\begin{array}{r}\text { Stan } \\
\text { bicarl } \\
(\mathrm{mm} \\
\text { After } \\
\text { preparation }\end{array}$ & $\begin{array}{l}\text { ndard } \\
\text { bonate } \\
\text { nol/l) } \\
\text { After auto- } \\
\text { regulation } \\
\quad \text { test }\end{array}$ \\
\hline Group 1 & $\begin{array}{l}\text { Normothermia no } \\
\text { trauma }\end{array}$ & $7.41 \pm 0.03$ & $7.44 \pm 0.3$ & $4.9 \pm 0.5$ & $6.0 \pm 0.7^{*}$ & $11.4 \pm 1.1$ & $12.0 \pm 3.4$ & $-1.1 \pm 2.1$ & $4.5 \pm 4.0^{*}$ & $24.8 \pm 1.5$ & $29.8 \pm 2.6^{*}$ \\
\hline Group 2 & $\begin{array}{l}\text { Hypothermia no } \\
\text { trauma }\end{array}$ & $7.41 \pm 0.06$ & $7.39 \pm 0.03$ & $5.0 \pm 0.3$ & $6.0 \pm 0.6^{*}$ & $11.5 \pm 2.4$ & $18.8 \pm 2.7^{*}$ & $-0.8 \pm 4.0$ & $-2.7 \pm 2.2$ & $25.1 \pm 3.0$ & $27.3 \pm 1.4$ \\
\hline Group 3 & $\begin{array}{l}\text { Normothermia } \\
\text { trauma }\end{array}$ & $7.41 \pm 0.03$ & $7.43 \pm 0.02$ & $4.8 \pm 0.3$ & $5.5 \pm 0.4^{*}$ & $10.7 \pm 1.4$ & $10.9 \pm 0.9$ & $-1.5 \pm 1.9$ & $3.4 \pm 1.4 *$ & $24.7 \pm 1.4$ & $27.9 \pm 0.9^{*}$ \\
\hline Group 4 & Hypothermia trauma & $7.38 \pm 0.02$ & $7.39 \pm 0.05$ & $4.8 \pm 0.2$ & $5.6 \pm 0.5^{*}$ & $12.0 \pm 2.3$ & $19.1 \pm 3.3^{*}$ & $-3.2 \pm 1.7$ & $0.7 \pm 3.6^{*}$ & $23.5 \pm 1.3$ & $26.0 \pm 2.4^{*}$ \\
\hline
\end{tabular}

*Indicates significant difference $v s$ the preparation value. $P<0.05$ 
deviate significantly from the overall mean value in group 1 .

The reduction of the animals' core temperatures from 38 to $30^{\circ} \mathrm{C}$ involved a linear decrease in the mean value of the SCBF from $99 \pm 3 \%$ to $68 \pm 14 \%$ of the base-line value. The recordings were made stepwise at every centigrade drop in core temperature. Regression analysis ( $\mathrm{SCBF} v s$ temperature) revealed a 3.5\% decrease in mean SCBF for every centigrade fall in core temperature $\left(\mathrm{r}^{2}: 0.98\right)$. The mean cooling time was $36 \pm 4 \mathrm{~min}$.

Group 3 Normothermic trauma group: A short and sharp rise in mean MABP from $98 \pm 4$ to $154 \pm 13 \mathrm{mmHg}$ was seen simultaneously with the onset of the spinal cord compression (Figure 2c). At the end of the compression the mean MABP had almost returned to pre-trauma values, and no alterations were seen during the rest of the experiment.

The mean SCBF decreased rapidly when the spinal cord compression was introduced, with lowest recordings obtained $(60 \pm 10 \%)$ as the blood-pressure peak started to decline. The decompression of the spinal cord resulted in a mean SCBF close to the base-line valued within 1 min. Regression analysis (SCBF vs time) revealed a slight reduction in mean SCBF following the spinal cord compression trauma of $0.2 \% / \mathrm{min}\left(\mathrm{r}^{2}: 0.7\right)$. The lowest mean $\mathrm{SCBF}$ value $(89 \pm 10 \%)$ was reached $45 \mathrm{~min}$ after the decompression.

Group 4 Hypothermic trauma group: The MABP recordings followed the same pattern as in group 3 including the initial rapid increase during the spinal cord compression (Figure 2d).

The mean SCBF also followed the same pattern as in group 3 during the compression trauma. After decompression the mean SCBF returned to the baseline within $2.5 \mathrm{~min}$ (the prolonged delay was a result of a low value in one animal). During the $15 \mathrm{~min}$ normothermic steady-state no SCBF alterations were recorded. The reduction of the animals' core temperatures from 38 to $30^{\circ} \mathrm{C}$ involved a linear decrease in mean SCBF, as in group 2, from $102 \pm 6$ to $78 \pm 11 \%$ of the base-line value. Regression analysis ( $\mathrm{SCBF}$ vs temperature) revealed a $2.8 \%$ decrease in mean SCBF for every centigrade fall in core temperature $\left(\mathrm{r}^{2}: 0.99\right)$. The mean cooling time was $30 \pm 5 \mathrm{~min}$.

\section{SCBF comparisons between the groups}

The comparisons of the mean SCBF values for each group are presented in Table 4. No significant differences were seen between the groups at the first point (a). The mean SCBF values for groups 2-4 differed significantly from the normothermic nontrauma group at the second point (b). At the third point (c) the mean SCBF values for groups $2-4$ also differed significantly from the normothermic nontrauma group, and there was also a significant difference between the normothermic trauma group and the hypothermic non-trauma group.

\section{Autoregulation tests}

The extraction of $2-5 \mathrm{ml}$ blood caused a fall in MABP of $30-50 \mathrm{mmHg}$ (Figure 3). No statistically significant decreases in mean SCBF were seen within any of the groups during the autoregulation procedure.

\section{Discussion}

In this investigation, the effects of systemic hypothermia and spinal cord compression trauma on SCBF were studied, using Laser-Doppler technique, which allowed a continuous blood flow recording throughout the entire experimental procedure. There was a linear correlation between the reduction of the esophageal temperature, within the range of 38 to $30^{\circ} \mathrm{C}$, and the decrease of SCBF independent of trauma prior to the lowering of the body temperature.

The Laser-Doppler method allows on-line blood flow recordings comparable to other methods of

Table 4 Statistical comparison of mean SCBF between the groups

\begin{tabular}{|c|c|c|c|c|c|c|c|c|c|}
\hline Groups & $\begin{array}{c}\text { Critical } \\
\text { SCBF } \\
\text { difference } \\
(\%)\end{array}$ & $\begin{array}{c}(a) \\
\text { Mean } \\
\text { SCBF } \\
\text { difference } \\
(\%)\end{array}$ & $\mathrm{P}$ value & $\begin{array}{c}\text { Critical } \\
\text { SCBF } \\
\text { difference } \\
(\%)\end{array}$ & $\begin{array}{c}(b) \\
\text { Mean } \\
\text { SCBF } \\
\text { difference } \\
(\%)\end{array}$ & $\mathrm{P}$ value & $\begin{array}{c}\text { Critical } \\
\text { SCBF } \\
\text { difference } \\
(\%)\end{array}$ & $\begin{array}{c}(c) \\
\text { Mean } \\
\text { SCBF } \\
\text { difference } \\
(\%)\end{array}$ & $\mathrm{P}$ value \\
\hline 1 vs 2 & 7.4 & 0.2 & 0.96 & 10.7 & 21.2 & $<0.01 *$ & 13.3 & 35.7 & $<0.01 *$ \\
\hline 1 vs 3 & 7.4 & 2.5 & 0.49 & 10.7 & 13.2 & $0.02 *$ & 13.3 & 15.0 & $0.03 *$ \\
\hline 1 vs 4 & 7.4 & 3.8 & 0.29 & 10.7 & 12.5 & $0.02 *$ & 13.3 & 26.3 & $<0.01^{*}$ \\
\hline 2 vs 3 & 7.4 & 2.7 & 0.46 & 10.7 & 8.0 & 0.13 & 13.3 & 20.7 & $<0.01 *$ \\
\hline $2 v s 4$ & 7.4 & 3.7 & 0.31 & 10.7 & 8.7 & 0.11 & 13.3 & 9.3 & 0.16 \\
\hline 3 vs 4 & 7.4 & 6.3 & 0.09 & 10.7 & 0.7 & 0.90 & 13.3 & 11.3 & 0.09 \\
\hline
\end{tabular}

The points (a), (b), and (c) are chosen to be equivalent between the groups. See Figure $2 \mathrm{a}-\mathrm{c}$. The 'Critical SCBF difference' is the least difference to give statistical significance and the 'Mean SCBF difference' is the actual mean difference between the groups. $P<0.05$ 


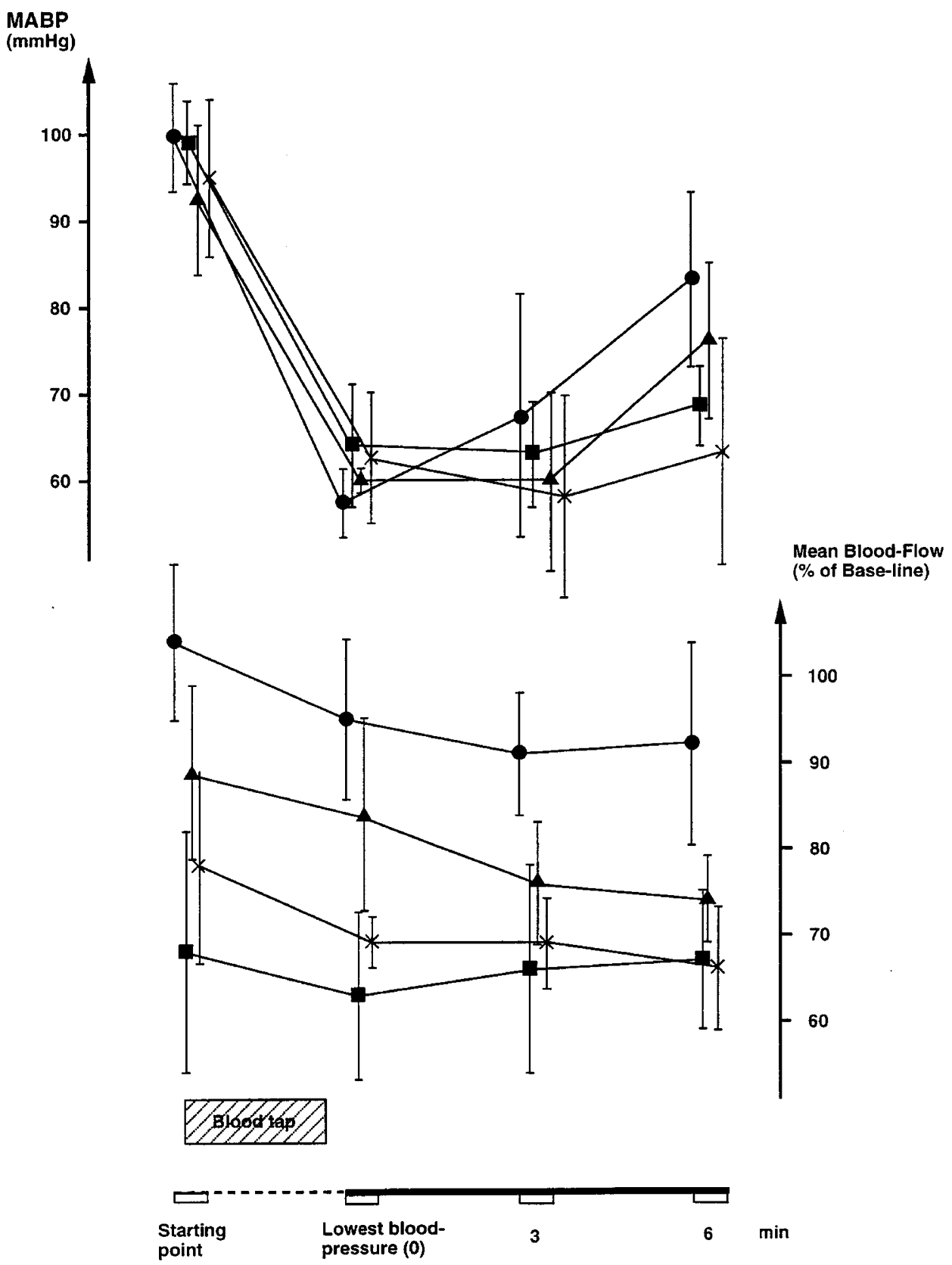

Figure 3 Autoregulation test. Mean MABP in actual values and SCBF in per cent (\%) of the base-line recordings \pm SD. Group $1(\mathbf{O})$, group $2(\boldsymbol{\square})$, group $3(\mathbf{\Delta})$ and group $4(\times)$

assessing microcirculation in the nervous system. ${ }^{11}$ The estimation of the tissue volume in which the bloodflow changes are recorded is, however, one major methodological problem. Karlsten et $a l^{31}$ used the same device as we did but with a fiber separation in the probe of $0.25 \mathrm{~mm}$. They evaluated the recorded depth using slices of spinal cord tissue and estimated the penetrated depth to at least $1 \mathrm{~mm}$. We used a probe with $0.5 \mathrm{~mm}$ fiber separation thus subsequently one would expect to cover a larger tissue volume. Although a maximum sampling volume of $1 \mathrm{~mm}^{3}$ tissue has been suggested for Laser-Doppler flowmetry ${ }^{15}$ reports of deeper penetration have been presented, for example, in bowel tissue. ${ }^{32}$ Given that a rat spinal cord is about $3 \mathrm{~mm}$ thick, we recorded the SCBF changes in the dorsal third of the spinal cord in the present investigation. This includes the posterior columns and parts of the central gray matter.

The sensitivity to movement artifacts is another well-known methodological problem. Even small movements of the probe will give recordings in a different vascular bed, making continuous interpreta- 
tions impossible. In our set-up, this was avoided by using a firm fixation of the probe and the animals together with Laser-Doppler flowmetry is not a straight line. Fluctuations are observed due to the cardiac cycle, artificial ventilation and rhythmic changes, probably due to variations in microcirculation. ${ }^{33}$ These factors could well explain the variation in recordings seen in the normothermic non-trauma group. Such changes seemed to be more pronounced closer to the injury zone, and we were unable to obtain stable recordings closer than $5 \mathrm{~mm}$ from the injury zone, which is similar to previous findings following brain contusion. ${ }^{34}$

The possibilities of comparing the effect of trauma on SCBF are very limited since we have to consider both the type and severity of trauma, and techniques for determinating SCBF. Most spinal cord injury research has been performed using the weight-drop technique, which probably exposes a different type of damage and ischemic process in the vascular bed. ${ }^{35,36}$

SCBF recordings are also available from studies using comparable trauma models, as in the present study, such as the extradural cuff/balloon and clip compression techniques and equivalent autoradiographic techniques. ${ }^{18,37,38}$ The SCBF recorded in these studies showed a similar reduction in the blood flow at the site of compression as well as cranial and caudal to the injury zones $1 \mathrm{~h}$ after trauma. This indicates that the blood changes recorded in the present study could be compared to the blood flowvalues obtained using the autoradiographic technique and the same trauma model. ${ }^{18}$

The Laser-Doppler flowmetry recorded a significant reduction of SCBF during the compression period. The SCBF returned close to the base-line within $1 \mathrm{~min}$ following the removal of the compression plate. This is not in accordance with our previous results, ${ }^{18}$ where we found a significant reduction of the SCBF values in white, but not in gray matter, $5 \mathrm{~mm}$ caudal to the injury zone at the end of the compression period. This area corresponds to the Laser-Doppler probe placement used in the present study.

A significant reduction of SCBF was observed using the autoradiographic technique in both white and gray matter after $5 \mathrm{~min}$ and remained so during the entire $60 \mathrm{~min}$ following trauma. In addition, the absolute values also decreased during that time. This decrease in SCBF was also observed in our Laser-Doppler recordings in the normothermic trauma group. The magnitudes of the decreases are, however, difficult to compare as the Laser-Doppler device probably records blood flow from both the gray and white matter. The examined area of the spinal cord, as well as the exact distance from the compression plate, is also less welldefined using Laser-Doppler technique compared to the high spatial resolution obtained from the autoradiographic studies.

The addition of systemic hypothermia irrespective of trauma exhibited a linear decrease in SCBF during the entire reduction of the body temperature, which is contrary to the findings of Sakamoto who used carbon- ${ }^{14}$-labeled butanol technique. ${ }^{28}$ This increase could, on the other hand, be explained by a simultaneous rise in blood-pressure and the use of $\mathrm{pH}$ correction for temperature. However, our results correspond with results from the brain ${ }^{27,39}$ and with experiments using local cooling of the spinal cord. ${ }^{29,30}$ The effect of systemic hypothermia on SCBF in our study exceeded the reduction recorded in the normothermic trauma group. No significant differences were seen between the two systemic hypothermic groups. The SCBF was reduced by $31 \%$ and $24 \%$ in the hypothermic non-trauma and trauma groups, respectively.

The physiological environment in the hypothermic situation is very complex, ${ }^{40}$ and several factors have to be considered. A lowering of the body temperature will reduce the general metabolism by about $5 \%$ per centigrade temperature decrease, ${ }^{26}$ resulting in diminished $\mathrm{O}_{2}$-consumption. ${ }^{24}$ The cardiac output is reduced in a linear fashion, but the MABP is less affected in the temperature range between 38 to $30^{\circ} \mathrm{C}^{41}$ This is probably achieved by a general vasoconstriction ${ }^{27}$ and increased blood viscosity. ${ }^{42}$ The acid-base status during the systemic hypothermia procedure could be managed either by correcting the $\mathrm{pH}$ according to normograms ( $\mathrm{pH}$-Stat) or the $\mathrm{pH}$ could be adjusted to pH 7.4 irrespective of the body temperature (alphastat). ${ }^{43}$ We used the alpha-stat approach during the hypothermic procedure, as the $\mathrm{pH}$-stat management seems to induce a relative hypercarbia. ${ }^{43}$ We found no differences in the autoregulatory capacity between any group, which is in agreement with Verhaeqen et al ${ }^{44}$ who used the same acid-base approach in the assessment of the cerebral autoregulation. ${ }^{43}$

On the basis of the present findings we conclude that the blood flow in the spinal cord follow the same patterns as in the brain during lowering of the core temperature. In the spinal cord the blood flow reduction caused by hypothermia exceeds the response mediated by moderate spinal cord compression trauma alone.

\section{Acknowledgements}

We wish to thank the artist Mats Linder for the illustration, Rolf Karlsten and Kjell Bakken for technical advice concerning the Laser-Doppler technique and Johan Bring for statistical advice.

\section{References}

1 Anderson DK, Hall ED. Pathophysiology of spinal cord trauma. Ann Emerg Med 1993; 22: 987-992.

2 Tator $\mathrm{CH}$, Fehlings MG. Review of the secondary injury theory of acute spinal cord trauma with emphasis on vascular mechanisms. J Neurosurg 1991; 75: 15-26.

3 Lipton SA, Rosenberg A. Excitatory amino acids as a final common pathway for neurologic disorders. N Engl J Med 1994; 330: $613-622$. 
4 Globus MY-T et al. Detection of free radical activity during transient global ischemia and recirculation: effects of intraischemic brain temperature modulation. J Neurochem 1995; 65: $1250-1256$

5 Li GL et al. Apoptosis and expression of bcl-2 after compression trauma to the spinal cord. J Neuropathol Exp Neurol 1996; 55: $280-289$.

6 Savitz SI, Rosenbaum DM. Apoptosis in neurological disease. Neurosurgery 1998; 42: 555-574.

7 Tator CH. Review of experimental spinal cord injury with emphasis on the local and systemic circulatory effects. Neurochirurgie 1991; 37: 291-302.

8 del Zoppo GJ. Microvascular changes during cerebral ischemia and reperfusion. Cerebrovasc Brain Met 1994; 6: 47-96.

9 Westergren et al. Systemic hypothermia following spinal cord compression injury in the rat: does recorded temperature in accessible organs reflect the intramedullary temperature in the spinal cord? J Neurotrauma 1998; 15: 943 - 954.

10 Oberg PA. Laser-Doppler flowmetry. Biomed Eng 1990; 18: 125 163.

11 Frerichs KU, Feuerstein GZ. Laser-Doppler flowmetry: a review of its application for measuring cerebral and spinal cord blood flow. Mol Chem Neuropathol 1990; 12: 55-70.

12 Skarpheidinsson JO, Hårding H, Thorén P. Repeated measurement of cerebral blood flow in rats. Comparison between the hydrogen clearance method and Laser Doppler flowmetry. Acta Physiol Scand 1988; 134: 133 - 142.

13 Lindsberg PJ et al. Validation of Laser-Doppler flowmetry in measurement of spinal cord blood flow. Am J Physiol 1989; 257: H674-H680.

14 Haberl RI, Heizer ML, Marmarou A, Ellis EF. Laser-Doppler assessment of brain microcirculation: effect of systemic alterations. Am J Physiol 1989; 256: H1247-H1254.

15 Bonner RF, Nossal R. Principles of Laser Doppler flowmetry. In: Shepherd AP, Öberg PÅ (eds). Laser Doppler flowmetry. Kluwer Academic Publishers: Boston, 1990, pp 17-45.

16 Anthes DL, Theriault E, Tator $\mathrm{CH}$. Ultra structural evidence for arteriolar vasospasm after spinal cord trauma. Neurosurgery 1996; 39: $804-814$

17 Holtz A, Nyström B, Gerdin B, Olsson Y. Neuropathological changes and neurological function after spinal cord compression in the rat. $J$ Neurotrauma 1990; 7: 155-167.

18 Holtz A, Nyström B, Gerdin A. Spinal cord blood flow measured by ${ }^{14} \mathrm{C}$-lodoantipyrine autoradiography during and after graded spinal cord compression in rats. Surg Neurol 1989; 31: 350-360.

19 Paulson OB, Strandgaard S, Edvinsson L. Cerebral autoregulation. Cerebrovasc Brain Metab Rev 1990; 2: 161 - 192.

20 Rubinstein A, Arbit E. Spinal cord blood flow in the rat under normal physiological conditions. Neurosurgery 1990; 6: $822-$ 886.

21 Guha A, Tator CH, Rochon J. Spinal cord blood flow and systemic blood pressure after experimental spinal cord injury in rats. Stroke 1989; 20: $372-377$.

22 Ohashi $\mathrm{T}$ et al. Correlation between spinal cord blood flow and arterial diameter following acute spinal cord injury in rats. Acta Neurochir 1996; 138: 322 - 329.

23 Hartung J, Cottrell JE. Mild hypothermia and cerebral metabolism. J Neurosurg Anesth 1994; 6: 1 -3

24 Hägerdal M, Harp J, Nilsson L, Siesjö BK. The effect of induced hypothermia upon oxygen consumption in the rat brain. $J$ Neurochem 1975; 24: $311-316$.
25 Ginsberg MD et al. Therapeutic modulation of brain temperature: relevance to ischemic brain injury. Cerebrovasc Brain Metab Rev 1992; 4: $189-225$.

26 Michenfelder JD, Milde JH. The relationship among canine brain temperature, metabolism, and function during hypothermia. Anesthesiology 1991; 75: 130-136.

27 Rosomoff HL, Holaday DA. Cerebral blood flow and cerebral oxygen consumption during hypothermia. Am J Physiol 1954; 179: $85-88$.

28 Sakamoto T, Monafo WW. The effect of hypothermia on regional spinal cord blood flow in rats. J Neurosurg 1989; 70: $780-784$

29 Hansebout RR, Lamont RN, Kamath MV. The effect of local cooling on canine spinal cord blood flow. Can J Neurol Sci 1985; 12: $83-87$.

30 Sakamoto T, Monafo WW. Regional spinal cord blood flow during local cooling. Neurosurgery 1990; 26: $958-962$

31 Karlsten R. Adenosine analogues for antinociception. Experimental studies in rodents on peripheral and intrathecal drug administration including assessment of spinal cord neurotoxicity. In: Comprehensive Summaries of Uppsala Dissertations from the faculty of medicine 431. Acta Universitas Upsaliensis 1993.

32 Ahn H, Lindhagen J, Nilsson GE, Öberg PÅ, Lundgren O. Assessment of blood flow in the small intestine with LaserDoppler flowmetry. Scand J Gastroenterol 1986; 21: 863-870.

33 Mizutani M, Yamamuro T, Shikata J. Vasomotion in normal and injured spinal cord. Exp Neurol 1988; 101: 256-266.

34 Nilsson P, Gazelius B, Carlsson H, Hillered L. Continuous measurement of changes in regional cerebral blood flow following cortical compression contusion trauma in the rat. $J$ Neurotrauma 1996; 13: $201-207$.

35 Senter HJ, Venes JL. Altered blood flow and secondary injury in experimental spinal trauma. J Neurosurg 1978; 49: 569-578.

36 Young W. Blood flow, metabolic and neurophysiological mechanisms in spinal cord injury. In: Becker DP, Povlischock JT, (eds). Central Nervous System Trauma Status Reports. National Institute of Neurological and Communicative Disorders and Stroke, National Institute of Health: 1985, pp 463-473.

37 Sandler AN, Tator CH. Effect of acute spinal cord compression injury on regional spinal cord blood flow in primates. $J$ Neurosurg 1976; 45: 660-676.

38 Rivlin AS, Tator $\mathrm{CH}$. Regional spinal cord blood flow in rats after severe cord trauma. J Neurosurg 1978; 49: 844-853.

39 Sakamoto T, Monafo WW. Regional blood flow in the brain and spinal cord of hypothermic rats. Am J Physiol 1989; 257: H785H790.

40 Sessler DI. Deliberate mild hypothermia. J Neurosurg Anesth 1995; 7: $38-46$.

41 Bullard RW. Cardiac output of the hypothermic rat. Am $J$ Physiol 1959; 196: 415-419.

42 Chen RYZ, Chien S. Hemodynamic functions and blood viscosity in surface hypothermia. Am J Physiol 1978; 235: H136- H143.

43 Swan H. The importance of acid-base management for cardiac and cerebral preservation during open heart surgery. Surg Gyn Obstetr 1984; 158: $391-414$.

44 Verhaegen MJJ, Todd MM, Hindman BJ, Warner DS. Cerebral autoregulation during moderate hypothermia in rats. Stroke 1993; 24: $407-414$. 